\title{
WATER QUALITY ASSESSMENT OF LAR STREAM, KASHMIR USING MACRO INVERTEBRATES AS VARIABLE TOLERANTS TO DIVERSE LEVELS OF POLLUTION
}

\author{
Muzaffar A. Ganie*, Amit Kumar Pal and Ashok Kumar Pandit ${ }^{1}$ \\ Institute of Environment and Development Studies, B. U. Jhansi (U.P.), India \\ ${ }^{1}$ Department of Environmental Sciences, University of Kashmir, Srinagar, India \\ *Email: lordslave123@gmail.com
}

\begin{abstract}
The present study conducted on "Lar stream" which is one of the principal left bank tributaries of the river Jhelum in the Valley of Kashmir (northern India), was an attempt to assess the water quality of the canal by using macro invertebrates present in the ecosystem. During the present study, a total of 26 species of macro invertebrates were registered from Lar stream which belonged to the orders Diptera, Trichoptera, Hirudinae, Ephemeroptera, Plecoptera, Gastropoda, Coleoptera, Arachnida, Lepidoptera, Crustacea, and Oligochaeta. Among all the eleven orders, Dipterans registered a highest of 7 species (27\%) and was the most dominant order. Then trend was followed by Trichoptera which registered a total of 5 species (19\%) and was the second most dominating group. Similarly, Ephemeroptera, Oligochaeta, Hirudinae, Plecoptera and Gastropoda which registered 2 species (8\%) each were the next dominating orders. The least representing taxa were Coleoptera, Arachnida, Lepidoptera and Crustacea which registered only one species (4\%) each during the entire study period. The present study concludes that presence of some pollution indicator species such as Tubifex tubifex, Limnodrilus sp. (among Annelida), Chironomous sp., Tabanus sp. etc. (among Arhropoda), Lymnea sp. (among Mollusca) point the changing status of the stream from non-polluted to polluted.
\end{abstract}

Key words: Macro invertebrates, water quality, river Jhelum, Lar stream, tributaries, Kashmir.

\section{INTRODUCTION}

Diversity and community composition macro invertebrate species are important themes in aquatic ecology, and are often used to evaluate environmental stress resulting from a variety of anthropogenic disturbances. These organisms have long been used as potential indicators of water quality in the rivers, streams, lakes, wetlands and other types of water bodies. Most interestingly, freshwater macro invertebrate species vary in sensitivity to organic pollution loads. In natural pristine conditions, high diversity and richness of species could be found (Armitage et al. 1983). However, high impacts due to human activities cause many changes to the assemblages and biodiversity of the stream and river fauna (Hellawell 1986 and Metcalf 1989). Macrobenthic invertebrates are an important and integral part of an aquatic ecosystem as they form the basis of trophic level and any negative effects caused by 
pollution in the community structure can in turn affect trophic relationships. According to Carlisle et al. (2007), macro invertebrate population in streams and rivers can assist in the assessment of the overall health of the stream. Human induced hydrological changes, physical disturbances (habitat alterations, land use) and point and nonpoint sources of pollution (chemical contamination surface run off, intensive agriculture) are the examples of processes responsible for a broad scale deterioration of lotic ecosystems (Chatzinik olaou et al. 2006). Macrobenthic invertebrates can thus be incorporated in the important technique of biological criteria assessment. Biological assessment can accordingly be used as the basis for management programmes, restoring and maintaining the chemical, physical and biological integrity of fresh water. Live organisms offer valuable information regarding their surrounding conditions and can be used to evaluate the physical, chemical and biological impact and their cumulative effects (Karr and Chu 1999). The abundance of benthic fauna greatly depends on physical and chemical properties of the substratum. Benthic macro invertebrates can be used as a barometer of overall biodiversity in aquatic ecosystems (Chatzinikolaou et al. 2006). The macrobenthic invertebrates can also be utilized in biological monitoring systems. Biological monitoring or biomonitoring is the systemic use of living organisms or their responses to determine the quality of the aquatic environment (Barbour and Paul 2010). Much of the traditional research on water quality focuses on physicochemical characteristics, but recent research has taken more of an interdisciplinary approach by including the relationships between water quality and biodiversity (Gower et al. 1994).

The present study conducted on "Lar stream" which is one of the principal left bank tributaries of the River Jhelum in the Valley of Kashmir (northern India), was an attempt to assess the water quality of the stream and justify the correlation between macro invertebrates found in such a stream and the water quality present during the period of study.

The major objective of this study was to assess the water quality of Lar stream, Kashmir, India.

The primary objectives of this study were:

1. To analyze the density and distribution of aquatic macro invertebrate community in Lar stream.

2. To assess the water quality using the variable diversity, distribution and density of macro invertebrates at different sites of the Canal.

\section{MATERIALS AND METHODS}

\section{Study site}

The present study focused on evaluating the ecological health of Lar stream Kashmir, in terms of its water quality utilizing the macro invertebrate communities as potential indicators of water quality during the study period January 2012 to May 2012. The selection of sites was a keen attempt to extract a better yield of results so that actual status of the ecological health of the particular ecosystem could be presented and strategies to manage and conserve such an ecosystem can be devised accordingly. Keeping in mind, such an unavoidable and important fact two sites were chosen for the study: Site I (Zawoora village) represented the natural unpolluted site and the site II (Wathoo village) stood for the polluted site. Comparative study of the stream at the two mentioned sites, in terms of absence, presence or abundance of macro invertebrate assemblages found would better reflect the water quality of the stream.

\section{Sampling schedule and procedure for macro invertebrate collection}

Sampling for macro invertebrate collection was carried out on monthly basis from January to May to assess the health of Lar stream, Kashmir, 
India. For macro invertebrate sampling in the stream, kick net and D-net samplers were used. The sediment and stones were disturbed immediate in upstream of the net by stirring it up using our feet so that the animals are dislodged and are swept into the net, which was located just downstream of our feet. The net was carefully rinsed several times in the stream to let the excess sediment pass through. The contents of the net were transferred into a bucket half-filled with water that was waiting at the stream bank.

Sorting: Sorting was performed at the site immediately after sampling. A position was selected to sort that was flat, and not in direct sunlight. The sample was gently mixed in the bucket to ensure that the contents are evenly distributed. Some or the entire sample was emptied into a white tray, which was having about $2 \mathrm{~cm}$ of clean water. The sample was allowed to settle and any movement in the water was observed. Any taxa that were seen were carefully collected using a spoon or a plastic pipette. The collected taxa were transferred into a white ice-block tray for a closer observation with a magnifying glass. The ice-block tray also was filled with clean water in the compartments. Similar macro invertebrates were placed into the same compartments. The sorting process took greater than 20 minutes as some taxa were quite hard to find.

Storing: The organisms were kept separately in different bottles after fixing them with $90 \%$ ethanol, $1 \%$ formaldehyde and $4 \%$ formalin. The preservation was done right at the time of collection.If the invertebrates were not treated with chemicals they were found to undergo excessive and irregular contraction. Insect larvae were preserved in $70 \%$ alcohol, a little glyserine was added to it to prevent damage caused by evaporation. Macro invertebrate classes/orders/ taxa were then identified and counted.

Identification of macro invertebrates: The organisms were identified both visually as well as with the help of microscope, and using the standard works of Edmondson (1959) and Adoni (1985) and a series of Fauna of British India.

Counting: When we completed the sorting and identification, then we marked down what we found on a macro invertebrate Data Sheet. Each type of organism was counted only once. As the sampling was done in an area of one sq $\mathrm{m}$ of the canal, the number of organisms per sq $m$ was the density of the particular organism. The collective contribution of a particular organism at a particular site was the overall density of the species at that particular site.

\section{RESULTS}

\section{Overall species composition}

During the present study, a total of 26 species of macro invertebrates were registered from Lar stream which belonged to the orders Diptera, Trichoptera, Hirudinae, Ephemeroptera, Plecoptera, Gastropoda, Coleoptera, Arachnida, Lepidoptera, Crustacea,and Oligocheata. Among all the eleven orders, Dipterans registered a highest of 7 species $(27 \%)$ and was the most dominating order. Then trend was followed by Trichoptera which registered a total of 5 species (19\%) and was the second most dominating group. Similarly, Ephemeroptera, Oligochaeta Hirudinae, Plecoptera and Gastropoda which registered 2 species (8\%) each were the next dominating orders. The least representing taxa were Coleoptera, Arachnida, Lepidoptera and Crustacea which registered only 1 species (4\%) each during the entire study period (Figs. 1 and 2) (Tables 1 and 2). 
Table 1. Various macro invertebrate taxa collected from the sampled study sites.

\begin{tabular}{|c|c|}
\hline Phylum/Order & Genus \\
\hline \multirow[t]{2}{*}{ Annelida/Oligochaeta } & Limnodrillus hoffmestri \\
\hline & Tubifex sp. \\
\hline \multirow[t]{3}{*}{ Annelida/Hirudinae } & Pelicopdella sp. \\
\hline & Erpobdella octoculata \\
\hline & Total \\
\hline \multirow[t]{2}{*}{ Arthropoda/Ephemeroptera } & Baetis sp. \\
\hline & Caenis sp. \\
\hline \multirow[t]{2}{*}{ Arthropoda/Plecoptera } & Perlodidae \\
\hline & Unidentified sp. \\
\hline \multirow[t]{5}{*}{ Athropoda/Trichoptera } & Hydropsychidae \\
\hline & Lepidostoma sp. \\
\hline & Glossosoma sp. \\
\hline & Brachycentrus sp. \\
\hline & Limnephillus sp. \\
\hline Arthropoda/Coleoptera & Elmidae \\
\hline \multirow[t]{7}{*}{ Arthropoda/Diptera } & Chironomus sp. \\
\hline & Diamesinae sp. \\
\hline & Tipula abdominals \\
\hline & Tabanus sp. \\
\hline & Atherix sp. \\
\hline & Psychodus sp. \\
\hline & Tipula abdominalis \\
\hline Arthopoda/Arachnida & Hygrobatoidae \\
\hline Arthropoda/Lepidoptera & Unidentified \\
\hline \multirow[t]{2}{*}{ Mollusca/Gastropoda } & Lymnaea auricularia \\
\hline & Lymnaea columella \\
\hline Arthropoda/Crustacea & Gammarus pulex \\
\hline
\end{tabular}

Table 2. Contribution of different macro invertebrate taxa at the two studied sites.

\begin{tabular}{llcccccccccc}
\hline Phylum/Order & Genus & Jan & Feb & $\begin{array}{r}\text { S-I } \\
\text { Mar }\end{array}$ & Apr & May & Jan & Feb & $\begin{array}{c}\text { S-II } \\
\text { Mar }\end{array}$ & Apr & May \\
\hline Annelida/ & Limnodrillus hoffmestri & 0 & 0 & 0 & 0 & 0 & 170 & 220 & 70 & 250 & 245 \\
Oligochaeta & Tubifex sp. & 0 & 0 & 0 & 0 & 4 & 0 & 0 & 0 & 3 & 13 \\
Total & & 0 & 0 & 0 & 0 & 4 & 170 & 220 & 70 & 253 & 258 \\
Annelida/ & Pelicopdella sp. & 0 & 0 & 0 & 0 & 3 & 0 & 0 & 3 & 0 & 12 \\
Hirudinae & Erpobdella octoculata & 0 & 0 & 2 & 0 & 0 & 5 & 15 & 25 & 25 & 27 \\
$\quad$ Total & & 0 & 0 & 2 & 0 & 0 & 5 & 15 & 28 & 25 & 39 \\
Arthropoda/ & Baetis sp. & 0 & 0 & 1 & & 2 & 0 & 1 & 0 & 0 & 0 \\
Ephemeroptera & Caenis sp. & & 2 & 0 & 0 & 3 & 0 & 0 & 0 & 0 & 2 \\
$\quad$ Total & & 0 & 2 & 1 & 0 & 0 & 0 & 1 & 0 & 0 & 2 \\
Arthropoda/ & Perlodidae & 1 & 0 & & & 1 & 0 & 0 & 3 & 0 & 0 \\
Plecoptera & Unidentified & 0 & 0 & 0 & 60 & 26 & 0 & 0 & 0 & 0 & 0 \\
$\quad$ & 1 & 0 & 0 & 60 & 0 & 0 & 0 & 3 & 0 & 0
\end{tabular}




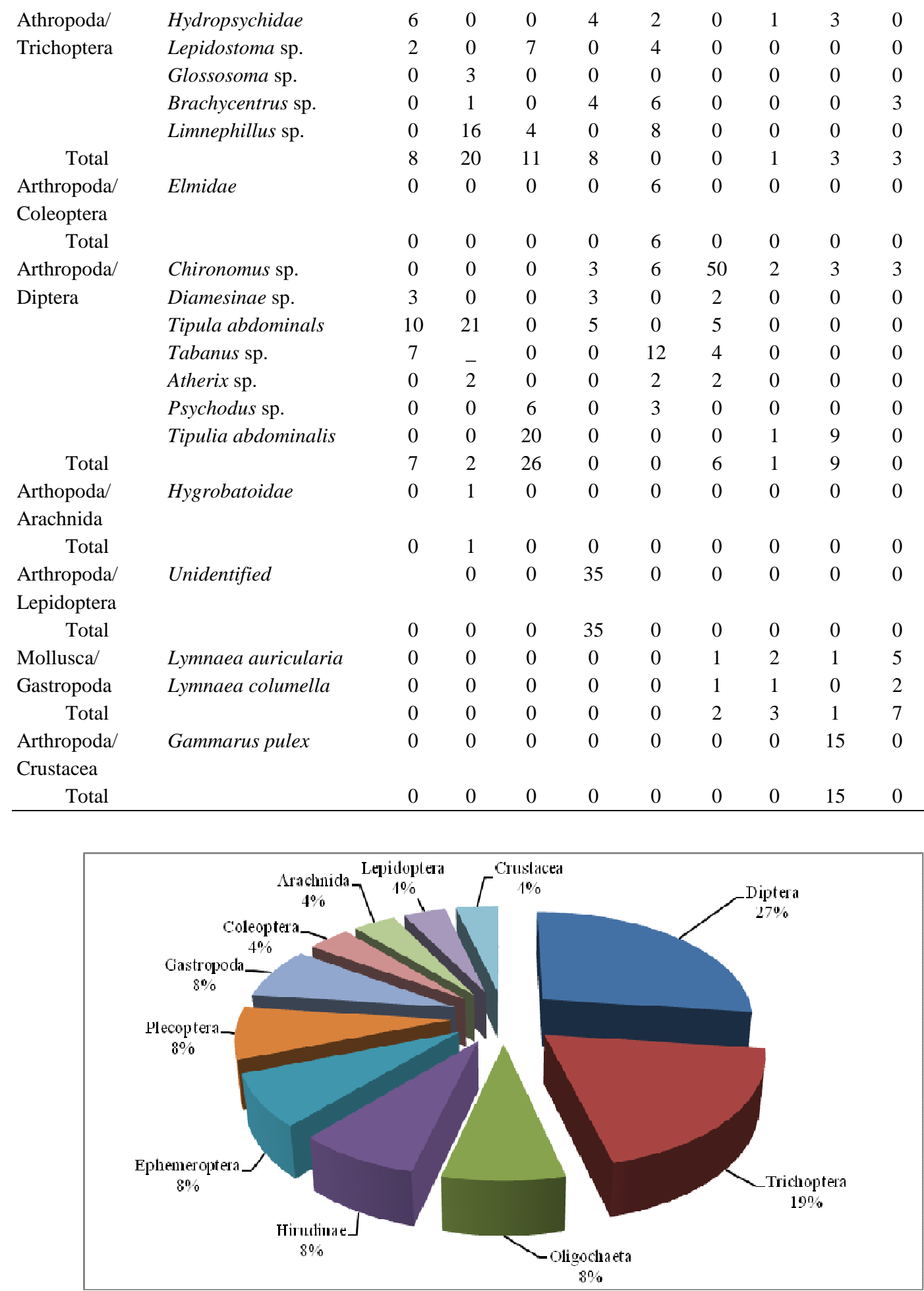

Fig. 1. Percentage contribution of macro invertebrate taxa at all sites during study period (Jan-May 2012). 


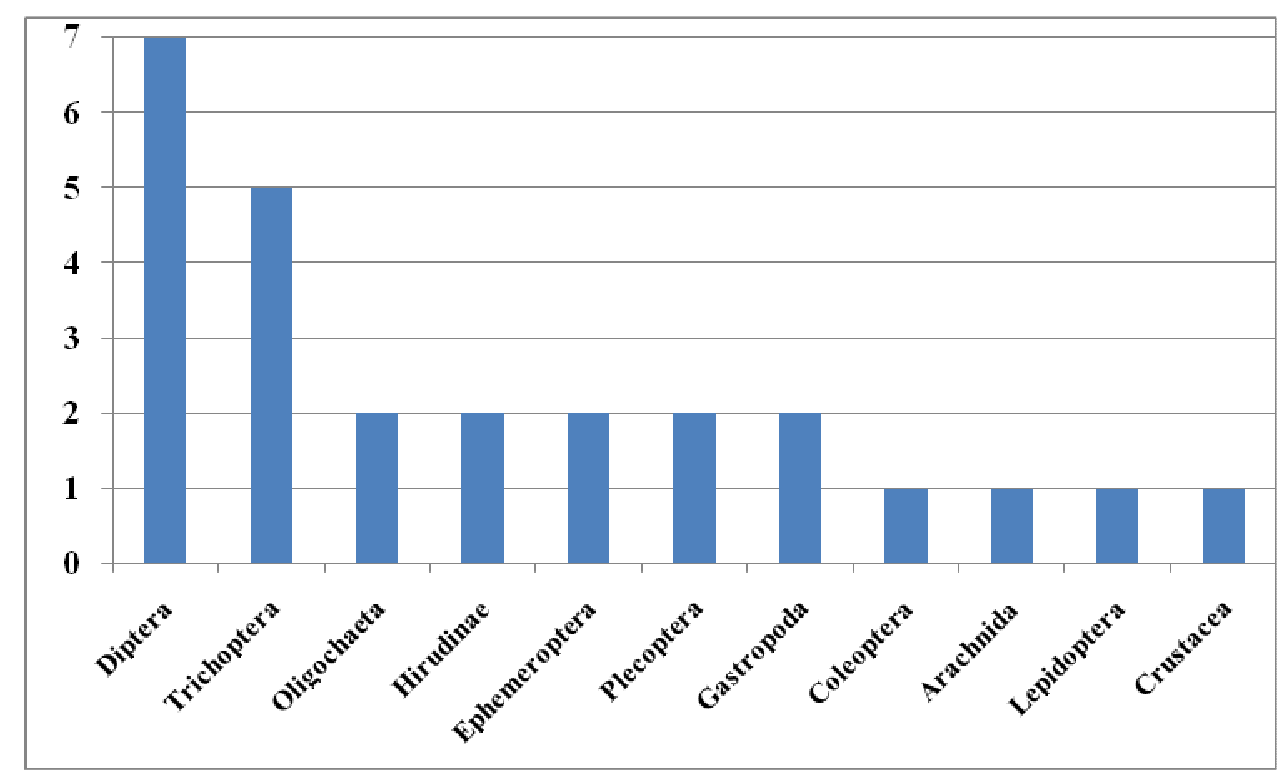

Fig. 2. Total number of macro invertebrate taxa at all sites during study period (Jan-May 2012).

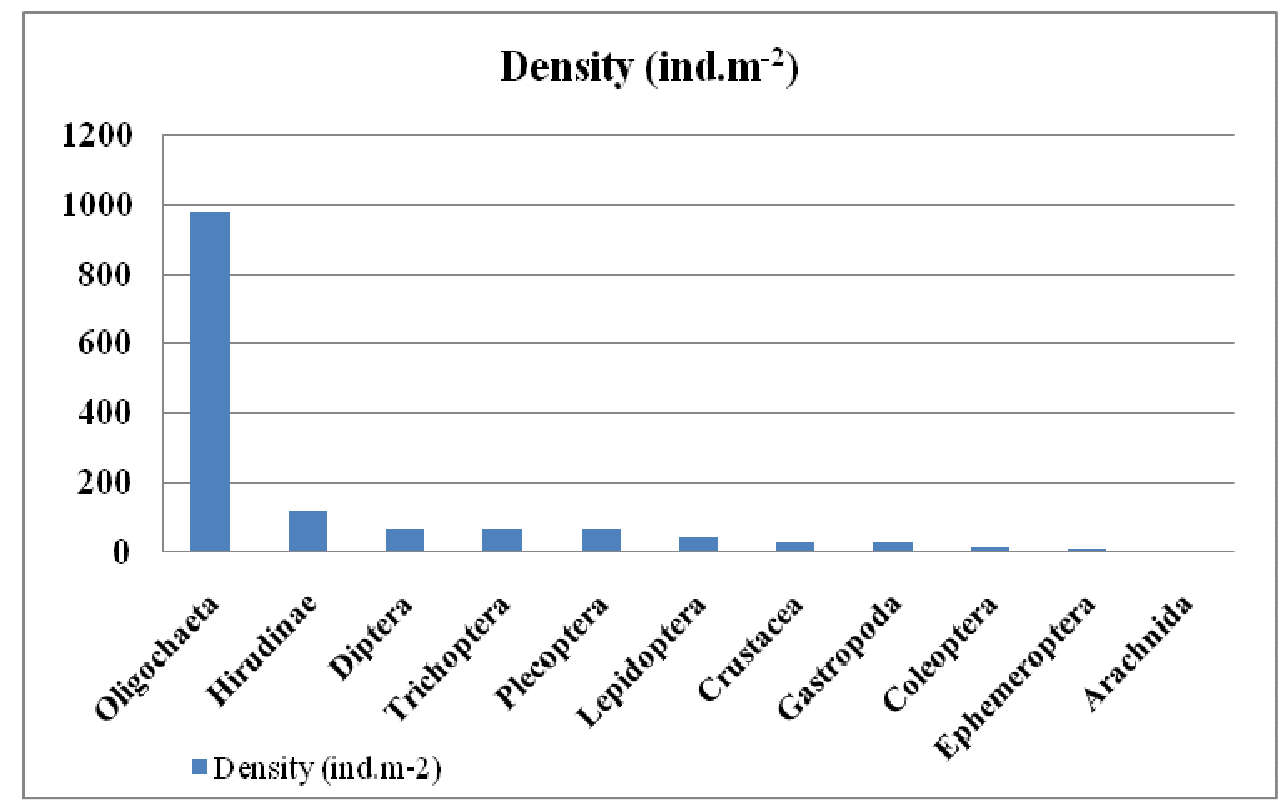

Fig. 3. Overall population density of macro invertebrates

Overall population density of macro invertebrates

Over all maximum population density of 975 ind. $/ \mathrm{m}^{2}$ was registered for oligochaetes and a least density of 1 ind. $/ \mathrm{m}^{2}$ was registered for Arachnida (Fig. 3). The trend of the overall density change as revealed by the study followed the pattern: 


\section{DISCUSSION}

In the present study, a total of 26 species of macro invertebrates belonging to Insecta, Gastropoda, Crustacea, Hirrudinaea, and Oligochaeta representing three main phyla Arthropoda, Mollusca, Annelida, were recorded from two sites of Lar stream, Kashmir. Among all the eleven orders, Dipterans registered a highest of 7 species $(27 \%)$ and was the most dominant order. Hutchinson (1993) concluded that Diptera are, by far, the most diverse order of insects in freshwaters. They are, in fact, the most diversified of any major taxon of freshwater organisms. The study revealed the presence of maximum number of Chironomus sp. which are invariably the inhabitants of polluted waters with low oxygen content and high organic matter (Pandit 1981). Oligochaetes have also been used to assess organic pollution and trophic status in water bodies (Millbrink 1994). The organic matter present in the stream at the polluted sites undergoes bacterial decomposition. The process requires a large amount of oxygen. As a result, the dissolved oxygen present in the water is rapidly used up. This limits the productive potential of the stream and also affects the distribution and abundance of macro invertebrate community. The presence of some pollution indicator species such as Tubifex tubifex, Limnodrilus sp. (among Annelida), Chironomous sp. and Tabanus sp. etc. (among Arhropoda), Lymnea sp. (among Mollusca) at site II directly points to the changing status of the stream from non-polluted to polluted.

Site I recorded maximum value of density and diversity due to least human interference. The low human population in its catchment resulted in maintaining the true ecological health of the stream at the site. This is also confirmed by the presence of Ephemeroptera, Trichoptera and Diptera at the site which are a characteristic feature of unpolluted waters. Similar findings were also reported by Bhat et al. (2011) Sharma and Chawdhary (2011) and Pandit et al. (2007) while working on limnological survey of some fresh water bodies in Kupwara region of Kashmir Himalaya also showed that the streams were poor in nutrients compared to springs and varied markedly in their biotic setup in terms of periphytic algae and macro invertebrates. Studies carried out by Shazia and Yousf on benthic macro invertebrate community of Yousmarg streams reported there was 'no apparent organic pollution' in Doodhganga stream as there is no source of pollution in its vicinity. However, in Khanshah manshah canal slight organic pollution is reported due inflow of organics from pasture and construction activity being carried out nearby. This variation in pollution status between the two streams resulted in considerable change in biotic set up as is the case in our study.

\section{CONCLUSION}

The lar stream harbored 26 species, out of them insects were well dominant in whole study area because of their potency to tolerate the organic pollution. The present study concludes that the presence of some pollution indicator species such as Tubifex tubifex, Limnodrilus sp. (among Annelida), Chironomous sp. and Tabanus sp. etc. (among Arhropoda), Lymnea sp. (among Mollusca) directly points to the changing status of the stream from non-polluted to polluted. The Lar Canal Kashmir, which was under the investigation has a vital ecological importance and is the backbone of agriculture and water supply schemes especially in two South Kashmir districts, Shopian and Pulwama. The said water body is under a severe ecological stress. Appropriate steps are thus needed to control human interference by sound management policy and relative measures before it is too late.

\section{REFERENCES}

Adoni, A.D. 1985. A Treatise on Limnology. The Zoobenthos. John Wiley and Sons, New York. Armitage, P.D., D. Moss, J.F. Wright and M.T.

Furse. 1983. Trophic structure of some typical wetlands. In: Wetlands-Ecology and Management (Part 1). (eds.) Gopal, B., R.E. 
Turner, R.G Wetzel and D.F. Whigam. Indian Sci. Publ. and National Institute of Ecology, India, pp. 55-82.

Barbour, M.T. and M.J. Paul. 2010. Benthic macro invertebrate community of Yousmarg streams (Doodganga stream and Khanshah Manshah canal) in Kashmir Himalaya, India. Journal of Ecology and the Natural Environment 4(11):280-289.

Bhat, S.U., A.H. Sofi, T. Yaseen, A.K. Pandit and A.R. Yousuf. 2011. Macro invertebrate assemblages as biological indicators of pollution in a central Himalayan river, Tawi (J\&K). International Journal of Biodiversity and Conservation 3(5):167-174.

Carlisle, D.M., M.R. Meador, S.R. Moulton and P.M. Ruhl. 2007. Freshwater Biology. John Wiley and Sons Inc., New York, London.

Chatzinikolaou Y., V. Dakos and D. Lazaridou. 2006. Macro invertebrate community from Sonamarg streams of Kashmir Himalaya. Pakistan Journal of Biological Sciences 14:182-194.

Edmondson, W.T. 1959. Limnological survey of some fresh waterbodies in Kupwara region of Kashmir Himalya. J. Himalyan Ecol. Sust. Dev. 2:973-7502.

Gower, A.M., G. Myers, M. Kent and M.E. Foulkes. 1994. Restoring Life in Running Waters- Better Biological Monitoring. Island Press, Washington, 206 pp.

Habib, S. and A.R. Yousuf. 2012. Biological Indicators of Freshwater Pollution and Environment Management. Elsevier, London.
Hellawell, J.M. 1986. Biological water quality assessment of running waters based on macro invertebrate communities: History and present status in Europe. Environmental Pollution 60:101-139.

Hutchinson, G.E. 1993. Adding value to water resource management through biological assessment of rivers. Hydrobiologia 651:1724.

Karr, J.R. and E.W. Chu. 1999. The performance of a new biological water quality score system based on macro invertebrates over a wide range of unpolluted running-water sites. Water Research 17:333-347.

Metcalf, J.L. 1989. Estimation and application of indicator values for common macro invertebrate. Ecol. Indicators 7:22-33.

Millbrink, G. 1994. Relationships between macro invertebrate communities and environmental variables in metal-contaminated streams in south-west England. Freshwater Biology 32:199-221.

Pandit, A.K and V. Kaul. 1981. Workbook on Limnology.

Pandit, A.K, H. Rashid, G.H. Rather and H.A. Lone. 2007. Longitudinal impacts of anthropogenic pressures on benthic macro invertebrate assemblages in a large transboundary Mediterranean river during the low flow period. Acta hydrochim. Hydrobiol. 34:453-463.

Sharma, K.K. and S. Chowdhary. 2011. Oligochaetes and water pollution in deep Norwegian lakes. Hydrobiologia 278:213-222. 